\title{
Institutional Analysis of Drinking Water Supply System in East Nusa Tenggara Province
}

\section{${ }^{1}$ I Gede Eko Putra Sri Sentanu, Muhammad Edo Edi Sriyiono}

\author{
${ }^{1}$ Universitas Brawijaya, Indonesia; sentanu@ub.ac.id \\ Received: July 12, 2021; In Revised: November 2, 2021; Accepted: December 20, 2021
}

\begin{abstract}
The regulatory mandate states that the implementation of the Drinking Water Supply System in the regions is prioritized for Regional Owned Enterprises as the Drinking Water Supply System manager. If Regional Owned Enterprises does not reach the Drinking Water Supply System services, then the implementation the Drinking Water Supply System remains the responsibility of the Central Government or Regional Governments may form a Technical Implementation Unit or Service Technical Implementation Unit to serve areas or areas that have not been reached by these services but can also be implemented by Community Groups and Business Entities to meet their own needs. This paper aims to analyze how the implementation of the Drinking Water Supply System in NTT Province with the perspective of Good Corporate Governance. The research method used is a literature review utilizing relevant journals, books, media, and laws and regulations. The results of this study indicate that the implementation of SPAM 2020 is mainly carried out by Regional Drinking Water Company (15 districts/cities from 22 districts/cities in NTT). The remaining seven districts are still in UPTD BLUD and UPTD. Institutions are essential to ensure that drinking water services to the community can be adequately served and ensure the functioning of the Drinking Water Supply System, both funded by the APBN and APBD.
\end{abstract}

Keywords: Local Government, Institutional, Good Corporate Governance, NTT

\section{Introduction}

East Nusa Tenggara (NTT) is a reasonably large province with 21 regencies and one city with 47,931 km2. Regional Drinking Water Company (PDAM) is a public service institution that provides or is engaged in drinking water. Some PDAMs are already managed within the Perumda institution, and some are still being encouraged to improve their institutional status in accordance with applicable laws and regulations.

From the report data on the performance of drinking water providers in the Province of NTT, out of 22 regencies/cities, 15 of them are already in the form of PDAMs, and seven units are in the form non-PDAMs (UPTD and UPTD PPK BLUD). With one sick unit, five unhealthy units and nine healthy units (BPKP, 2020), and seven from regencies/cities still in the form of Regional Technical Implementation Units (UPTD), 3 of them were only formed at the end of 2020 even though the adequacy and availability drinking water by drinking water providers is essential.

The problems and constraints experienced by PDAMs will impact the Drinking Water Management System (SPAM). In addition, these obstacles are not in accordance with the aspects of good governancewhich includes accountability, transparency and responsiveness. Compliance and compliance must be in accordance with the principles of good corporate 
governance. There are five principles of good corporate governance, among others, the principle of independence, the principle of accountability, the principle of responsibility, justice, and transparency (Cahyono \& Wati, 2019). In accordance with the mandate stated in the 1945 Constitution Article 33 paragraph 3, which reads, "Earth, water and the wealth contained therein are controlled by the state and used as much as possible for the prosperity of the people". In accordance with this mandate, the government should strive to realize the prosperity of the people through the availability of drinking water.

Institutionality in SPAM is a crucial and influential element. This is supported by a scientific paper entitled "SWOT analysis of the implementation of a sustainable drinking water supply system (green SPAM) at the Keburejo Regional SPAM in Central Java" this study explains the importance of SPAM, as for the strengths of sustainable SPAM as follows, water quality and quantity good standard; local government commitment in realizing the SPAM development program; the existence of special regional SPAM regulations (PKS, PERGUB); the presence of a particular management agency; people's desire to get clean water services (Guritno, 2018). Therefore, according to this study, the existence of SPAM institutions is fundamental to meeting the needs of clean water by the surrounding community.

The governance framework model uses the Deloitte model, which uses risk elements, compliance with regulations and morals. In general, the Deloitte model of governance framework consists of a governance board and corporate governance infrastructure. Board governance is a job that cannot be replaced or represented to management because it is a form of accountability from the board. In contrast, corporate governance infrastructure is the opposite of board governance, a job that management can replace or represent. Then the board becomes a supervisor. (Abdurrahman \& Pahlavi, 2018).

Figure 1

Deloitte's Corporate Governance Model

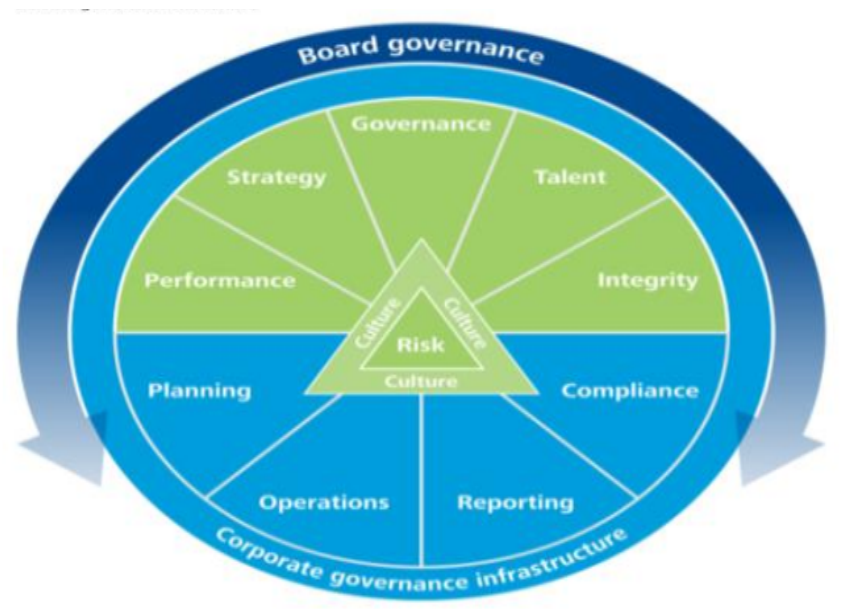

Source: (Abdurrahman \& Pahlavi, 2018)

The description of the image of the Deloitte model of the corporate governance framework is as follows: (Abdurrahman \& Widhar Pahlevi, 2018). First, the core of the Dellit model is the company culture and risk, which will influence and impact the effectiveness of all elements of the work structure. Second, corporate governance infrastructure is the company's entire form/operational model that involves all aspects. This is an effort by the management to carry out the company's direction through the planning, implementation, reporting processes 
and remaining obedient to the applicable regulations and morals. Third, a governance board is a place where the board is responsible for everything and must be actively involved in it, understanding and implementing.

Good Corporate Governance (GCG) is the relationship between the top management of the company, which consists of the BoD, senior managers, and stakeholders, which is a mechanism that gives the authority to control the company based on decisions made by top management (Abdurrahman \& Pahlavi, 2018). Good corporate governance is an institutional optimization effort that will make a company or institution up and running effectively and with accountability. Several agencies have tried to provide basic guidelines which are often referred to as the principles of implementing good corporate governance practices, including the Organization for Economic Cooperation and Development (OECD), putting forward four essential elements of good corporate governance, namely: transparency, accountability, fairness and responsibility (Anggionaldi, 2018). Implementing sound corporate governance in a company will provide adequate protection for all parties. And the operation of the institution or company will run well and according to the expected target.

\section{Methods}

This study uses a literature study data collection method where researchers use scientific articles, journals and previous studies to find and collect relevant data for this research. Then this research was conducted at the SPAM institution of East Nusa Tenggara Province (NTT). Researchers collect secondary data by analyzing articles related to this research. In addition, researchers made observations on the object of research to find additional data for research purposes. The researcher also conducted a literature study to prove the differences in research and the urgency of the study conducted by the researcher.

\section{Results and Discussion}

The organizers of the Drinking Water Supply System (SPAM) in the NTT Province in 2021 consist of 15 BUMD, 6 UPTD, and 1 UPTD PPK BLUD. The areas managed by BUMD are Kupang City, East Sumba Regency, Kupang Regency, South Middle East Regency, North Middle East Regency, Belu Regency, Alor Regency, Alor Regency, Lembata Regency, East Flores Regency, Sikka Regency, Ende Regency, Ngada Regency, Manggarai Regency, Rote Ndao Regency, and West Manggarai Regency. Meanwhile, the areas managed by the UPTD are Central Sumba Regency, West Sumba Regency, Southwest Sumba Regency, Sabu Raijua Regency, East Manggarai Regency, and Malacca Regency. Meanwhile, the area managed by the BLUD is Nagekeo Regency.

Figure 2

Institutional SPAM in NTT Province in 2021

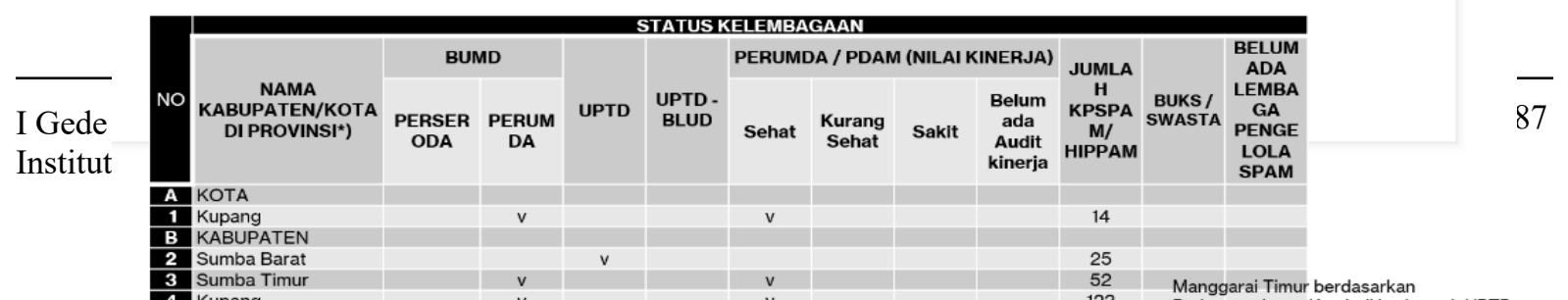


Based on the data above, the institutional performance of the drinking water supply system managed by BUMD shows that 9 BUMDs are healthy, 5 BUMDs are unhealthy, and 1 BUMD is sick. Meanwhile, the UPTD and BLUD that manage SPAM currently have no performance appraisal, and monitoring-evaluation is being carried out to see the institutional performance. In 2020, in NTT Province, 3 SPAM UPTDs was formed in 3 districts (West Sumba Regency, Southwest Sumba Regency, and Malacca Regency). Meanwhile, for East Manggarai Regency in 2021, based on East Manggarai Regent Regulation Number 30 of 2021, the SPAM institutional status from the previous BLUD was changed back to UPTD.

Figure 3

BUMD Performance in NTT Province SPAM Operators

\begin{tabular}{|c|c|c|c|c|c|c|c|c|c|c|c|}
\hline No. & $\begin{array}{l}\text { BumD } \\
\text { Penyelenggara } \\
\text { SPAM }\end{array}$ & $\begin{array}{c}\text { Nilai } \\
\text { Tahun } \\
\text { Buku } 2018\end{array}$ & Kinerja & \begin{tabular}{|c|c} 
Cakupan \\
Pelayanan \\
$(\%)$
\end{tabular} & 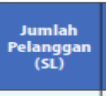 & $\begin{array}{l}\text { Efektivitas } \\
\text { Penagihan } \\
\text { (\%) }\end{array}$ & $\begin{array}{c}\begin{array}{c}\text { Tingkat } \\
\text { Kehilangan } \\
\text { Air } \\
(96)\end{array} \\
\end{array}$ & $\begin{array}{c}\text { Tarif Rata- } \\
\text { Rata- } \\
(\text { Rp/m3) }\end{array}$ & $\begin{array}{c}\text { HPP } \\
\text { dengan } \\
\text { NRW Riil } \\
(\text { Rp/m3) }\end{array}$ & $\begin{array}{c}\text { Selisih Tarif } \\
\text { Rata-Rata } \\
\text { dan HPP } \\
\text { NRW Rilil } \\
\text { (Rp/m3) }\end{array}$ & $\begin{array}{l}\text { FCR } \\
\text { NoN } \\
\text { FCR }\end{array}$ \\
\hline 1 & $\begin{array}{l}\text { PDAM Tirta Komodo } \\
\text { Kabupaten Manggarai }\end{array}$ & 3,45 & SEHAT & $43,00 \%$ & 21.217 & $97,21 \%$ & $20,88 \%$ & 3.277 & 3.547 & (269) & Non FCR \\
\hline 2 & $\begin{array}{l}\text { PDAM Matawai Amahu } \\
\text { Kabupaten Sumba } \\
\text { Timur }\end{array}$ & 3,37 & SEHAT & $31,86 \%$ & 9.297 & $85,88 \%$ & $30,70 \%$ & 3.262 & 3.136 & 125 & FCR \\
\hline 3 & $\begin{array}{l}\text { PDAM Tirta Lontar } \\
\text { Kabupaten Kupang } \\
\end{array}$ & 3,17 & SEHAT & $16,93 \%$ & 23.805 & $90,81 \%$ & $23,67 \%$ & 7.777 & 6.948 & 830 & FCR \\
\hline 4 & $\begin{array}{l}\text { PDAM Kabupaten } \\
\text { Flores Timur } \\
\end{array}$ & 3,02 & SEHAT & $37,00 \%$ & 7.007 & $90,81 \%$ & $22,30 \%$ & 5.010 & 5.294 & (285) & Non FCR \\
\hline 5 & $\begin{array}{l}\text { PDAM Tirta Cendana } \\
\text { Kabupaten Timor } \\
\text { Tengah Utara } \\
\end{array}$ & 2,97 & SEHAT & $12,71 \%$ & 3.478 & $91,46 \%$ & $24,99 \%$ & 3.543 & 4.716 & (1.172) & Non FCR \\
\hline 6 & $\begin{array}{l}\text { PDAM Kabupaten } \\
\text { Lembata }\end{array}$ & 2,91 & SEHAT & $52,98 \%$ & 4.343 & $95,66 \%$ & $25,82 \%$ & 3.022 & 3.415 & (393) & Non FCR \\
\hline 7 & $\begin{array}{l}\text { PDAM Tirta Bening } \\
\text { Lontar Kota Kupang } \\
\end{array}$ & 2,86 & SEHAT & $12,28 \%$ & 10.124 & $84,01 \%$ & $23,99 \%$ & 7.653 & 7.259 & 394 & FCR \\
\hline 8 & PDAM Kabupaten Sikka & 2,84 & SEHAT & $33,58 \%$ & 15.242 & $93,02 \%$ & $33,56 \%$ & 4.851 & 5.613 & (762) & Non FCR \\
\hline 9 & $\begin{array}{l}\text { PDAM Nusa Kenari } \\
\text { Kabupaten Alor } \\
\end{array}$ & 2,64 & $\begin{array}{l}\text { KURANG } \\
\text { SEHAT }\end{array}$ & $25,81 \%$ & 5.325 & $153,13 \%$ & $46,21 \%$ & 1.994 & 1.193 & 801 & $\mathrm{FCR}$ \\
\hline 10 & $\begin{array}{l}\text { PDAM Tirta Kelimutu } \\
\text { Kabupaten Ende }\end{array}$ & 2,48 & $\begin{array}{l}\text { KURANG } \\
\text { SEHAT }\end{array}$ & $21,62 \%$ & 11.344 & $88,44 \%$ & $34,73 \%$ & 4.239 & 5.173 & (933) & Non FCR \\
\hline 11 & $\begin{array}{l}\text { PDAM Wae Mbeliling } \\
\text { Kabupaten Manggarai } \\
\text { Barat }\end{array}$ & 2,41 & $\begin{array}{c}\text { KURANG } \\
\text { SEHAT }\end{array}$ & $18,82 \%$ & 6.054 & $54,64 \%$ & $31,01 \%$ & 3.468 & 6.572 & (3.104) & Non FCR \\
\hline 12 & $\begin{array}{l}\text { PDAM Tirta Banari } \\
\text { Kabupaten Ngada }\end{array}$ & 2,35 & $\begin{array}{l}\text { KURANG } \\
\text { SEHAT }\end{array}$ & $44,08 \%$ & 9.349 & $72,41 \%$ & $20,42 \%$ & 5.441 & 5.773 & (332) & Non FCR \\
\hline 13 & $\begin{array}{l}\text { PDAM Atambua } \\
\text { Kabupaten Belu }\end{array}$ & 2,29 & $\begin{array}{l}\text { KURANG } \\
\text { SEHAT }\end{array}$ & $10,73 \%$ & 2.905 & $92,17 \%$ & $31,69 \%$ & 6.557 & 6.510 & 48 & FCR \\
\hline 14 & $\begin{array}{l}\text { PDAM Kabupaten Timor } \\
\text { Tengah Selatan }\end{array}$ & 2,21 & $\begin{array}{c}\text { KURANG } \\
\text { SEHAT }\end{array}$ & $12,54 \%$ & 7.156 & $91,49 \%$ & $29,96 \%$ & 3.758 & 4.007 & (248) & Non FCR \\
\hline 15 & $\begin{array}{l}\text { PDAM Rote Ndao } \\
\text { Kabupaten Rote Ndao }\end{array}$ & 1,75 & SAKIT & $13,57 \%$ & 4.140 & $93,23 \%$ & $46,14 \%$ & 4.465 & 5.475 & (1.010) & Non FCR \\
\hline
\end{tabular}

Source: Indonesia's National Government Internal Auditor, 2020

Based on the data in Figure 3 above, it can be seen that the coverage of SPAM services by BUMD that administers SPAM in NTT Province is still relatively low, with an average service coverage of $25.83 \%$. The highest service coverage is in Lembata Regency, namely $52.98 \%$, and the most insufficient service coverage is in Belu Regency, namely $10.73 \%$. There are 140,786 customers served by BUMD implementing SPAM, with the highest number of customers in Kupang Regency, as many as 23,805 customers, and the least number of 
customers in Belu Regency, as many as 2,905 customers. The level of water loss in implementing SPAM by BUMD that administers SPAM in NTT Province is still relatively high, reaching an average of up to $29.73 \%$.

The effectiveness of billing for SPAM administration by BUMD that administers SPAM is very high, reaching an average of $91.62 \%$. The average tariff for SPAM implementation by BUMD that assists SPAM is Rp. 4,554.47, with the lowest tax being in Alor Regency at Rp. 1,994.00 and the highest tariff being in Kupang City at Rp. 7,777.00. The average cost of goods sold with non-revenue water (real NRW HPP) in BUMD SPAM operators in NTT Province is Rp.4,974.73, with the highest real NRW HPP in Kupang City at Rp.7,259.00 and the lowest real NRW HPP is in Alor Regency at Rp.1, 193.00. The implementation of SPAM by 10 BUMDs in the NTT Province is still in non-full cost recovery (Non-FCR) status, and 5 BUMDs have full cost recovery (FCR) status. said PDAM is still experiencing losses.

Water is one of the basic needs of society that must be met in living their daily lives. This lack of safe drinking water will impact the Human Development Index (HDI) because it is related to meeting the needs of people's lives in a country(Saputra \& Nur, 2019). Government Regulation Number 2 of 2018 concerning Minimum Service Standards article 7 states that the fulfilment of drinking water for the community is one of the development priorities for Regency/City Governments. The position of the Provincial Government is as a coordinator, or the central government can only provide stimulus and technical guidance in the context of implementing access to drinking water. Institutional aspects and sustainability of SPAM management are crucial in determining whether the implementation of SPAM in an area has been running well or not. Therefore, institutional, financial and HR performance needs to get the attention of SPAM organizers and Regency/City Governments (Directorate General of Human Settlements, 2019). In his research,

According to Mukherje, N \& van Wijk (2003) in Trijunianto (2016: 8) said that there are 5 (five) aspects of sustainability for drinking water and sanitation development, namely: technical, social, financial, environmental, and institutional (Swastomo \& Iskandar, 2020). Institutional criteria in supporting SPAM development are as follows: a). Institutional and financial management; b). water loss; c). Cooperation between the government and local governments and collaboration between local governments; d). Government cooperation with business entities; and e). Cooperation between business entities (Satrya Alamsyah et al., 2020). Meanwhile, according to the NTT Provincial Representative BPKP in the 2019 Performance report, it explained the achievement of the realization of BUMD whose performance had at least a good predicate from the BUMD evaluated, reaching $60 \%$ or 9 BUMD with a good predicate out of 15 BUMD fostered in the 2019 BUMD evaluation (Directorate General of New Renewable Energy and Energy Conservation, 2020). Organizational strengthening is a strategy that an institution must carry out to answer the problems being faced. The synergy between stakeholders has an important role, especially between regulators (Technical Service) and operators (SPAM organizers).

The Central Government and Regional Governments (PEMDA) need to encourage so that business planning documents are compiled for Regional Owned Enterprises (BUMD) as institutions that provide SPAM that accesses $100 \%$ of drinking water which refers to the RPJMN, RPJMD, policies and regional methods in the field of SPAM development, and can be implemented in the RKAP of BUMD SPAM organizers to encourage the realization of drinking water quality (not just clean water) from the processing carried out by BUMD SPAM operators in accordance with the Minister of Health Regulation No. 492 of 2010 concerning 
Drinking Water Quality Requirements and to improve its supervision in accordance with the Minister of Health Regulation No. 736 of 2010 concerning Procedures for Supervision of Drinking Water Quality.

Employee competency improvement can be made periodically. The Board of Directors of BUMD that administers SPAM can improve the quality of employee performance by utilizing training activities organized by the drinking water engineering centre, PERPAMSI, and other similar training institutions or can develop the quality of employees and can conduct training internally at BUMD that administers SPAM by inviting certified resource persons/presenters / accredited and can take advantage of central programs related to capacity building. In addition, the seriousness of the management of BUMD that organizes SPAM and assistance and support from the local government is needed in suppressing non-revenue water (NRW).

Based on the problems above, it can be concluded that the implementation of SPAM by PDAM as BLUD has weaknesses, such as poor management and limited access to funding. This is due to low coverage, high NRW, idle capacity, high debt arrears, and not bankable. The Department of Public Works and Public Housing, a specialized agency, has a regulatory function to become one of the tasks and functions of the fields/sections that make up the UPTD by increasing the UPTD to UPTD PPK BLUD. Therefore, the implementation and management of SPAM carried out by organizational service units such as the Division/Section, UPTD and BLUD are more of a technical function in SPAM. Meanwhile, the implementation and management of SPAM carried out by BUMDs such as Perumda and Perseroda is more concerned with regional needs and the feasibility of regional business functions. According to Government Regulation Number 54 of 2017 concerning Regional-Owned Enterprises, article 9 explains that the feasibility of the BUMD business sector is reviewed through an analysis of economic feasibility, market and marketing analysis, financial feasibility analysis, and analysis of other aspects.

On the other hand, Full Cost Recovery (FCR) is the full use of costs namely, the average PDAM tariff must be able to reach the minimum price or the lowest limit equal to the PDAM's essential cost. Implementing FCR rates is critical in meeting maintenance, development and other operational expenses. Full Cost Recovery (FCR) is the full use of fees, namely, the average PDAM tariff must be able to reach the minimum price or the lowest limit equal to the PDAM's essential cost. Implementing FCR rates is crucial in meeting maintenance, development, and other operational expenses. Full Cost Recovery (FCR) is the full use of fees, namely, the average PDAM tariff must be able to reach the minimum price or the lowest limit equal to the PDAM's essential cost. Implementing FCR rates is crucial in meeting maintenance, development and other operational expenses (Saputra \& Nur, 2019). Full Cost Recovery (FCR) is a reaction variable to determine finances, income, and expenditure on SPAM management, both by UPTD and PDAM. The greater the PDAM's income, the greater the chance of achieving FCR. Meanwhile, the greater the cost used for expenses, the smaller the opportunity to achieve FCR. Therefore, the size of the tariff determines the chance of attaining FCR.

\section{Conclusion}

The availability of drinking/clean water is necessary for all people to meet their daily needs. The community to meet water needs is very dependent on the availability of physical infrastructure and the ability or performance of the SPAM organizers. The affordability and sustainability of SPAM need to get the attention of stakeholders, especially local governments, starting from aspects of planning, implementation, monitoring and evaluation. Therefore, institutional performance related to the principles of Good Corporate Governance (such as 
organizational and employee commitment, corporate managerial governance by the board of directors, the effectiveness of the supervisory board, public information disclosure and others), financial performance, and human resource management need to be considered and transparent benchmarks and controls. On the other hand, PDAMs in the province of NTT also face obstacles, namely the need for synergy between stakeholders in SPAM such as the Technical Service as the regulator, the SPAM organizer as the operator and the regional planning agency (Bappeda/Bappelitbangda). In the institutional aspect, institutional strengthening (capacity building) and increasing institutional status are common concerns to improve performance and service to the community.

\section{References}

Abdurahman, A., \& Widhar Pahlevi, R. (2018). Procedure for implementing the Principles of Good Corporate Governance in the Corporate Social Responsibility Program at the Regional Company PDAM, Bantul Regency. JBTI : Journal of Business Theory and Implementation, 9(1), 76-88. https://doi.org/10.18196/bti.91101

Anggionaldi, M. (2018). Effect of Effectiveness of Internal Control, Internal Audit Function and Implementation of Good Corporate Governance on Financial Performance. Faculty of Economics and Business, Jenderal Achmad Yani University, 15(1), 74-94.

Cahyono, D., \& Wati, CHS (2019). Analysis of the Principles of Good Corporate Governance on Company Performance. Musamus Accounting Journal, 2(1), 44-49.

Directorate General of New Renewable Energy and Energy Conservation. (2020). 2019 Performance Report. Ministry of Energy and Mineral Resources, 3, 1-50.

Directorate General of Human Settlements. https://ciptakarya.pu.go.id/v5/berita/detail/Ciptakarya/10212/Institutional-SPAM-InUpayaPeningkatan-Penyelenggaraan-SPAM

Guritno, A. (2018). SWOT Analysis of the Implementation of a Sustainable Drinking Water Supply System (Green Spam) at the Keburejo Regional Spam. September, 203-219.

Saputra, AP, \& Nur, MI (2019). 6311-17315-2-Pb. Journal of Bureaucracy \& Local Government, 1(November), 1-18.

Satrya Alamsyah, R., Fauzi, M., \& Sandhyavitri, A. (2020). Formulating a Strategy for the Development of the Dumai City Drinking Water Supply System (SPAM) using AHP (Analytical Hierarchy Process). Unitek Journal, 11(1), 24-39. https://doi.org/10.52072/unitek.v11i1.26.

Sentanu, IGEPS, \& Khoirunisa, M. (2020, November). Can Institutional Capacity Building Improve Farmer's Welfare?. In 2nd Annual International Conference on Business and Public Administration (AICoBPA 2019) (pp. 298-302). Atlantis Press.

Swastomo, AS, \& Iskandar, DA (2020). Sustainability of Community-Based Rural Water Supply System. Sukowati Research and Development Journal: Research and Development Media, 4(2), 14. https://doi.org/10.32630/sukowati.v4i2.131.

Trijunianto, O. (2016). Analysis of Sustainability Factors for Drinking Water Facilities for the Pamsimas Program in Kupang Regency, East Nusa Tenggara Province. Thesis. Ten November Institute of Technology. 
Publica: Jurnal Pemikiran Administrasi Negara

P-ISSN 2085-6555

Vol 13 No. 2 | Desember 2021: 185-192

E-ISSN 2715-9256

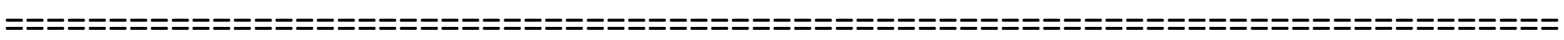

